\title{
Peningkatkan Prestasi Matematika Pada Siswa KelasVIII dengan Student Teams-Achievement Division
}

\author{
Agung Cahyo Hartono \\ SMP Negeri 2 Sukoharjo \\ agungcahyohartono@yahoo.com
}

\begin{abstract}
ABSTRAK
Penelitian ini bertujuan untuk meningkatkan prestasi belajar Matematika materi Lingkaran melalui penggunaan model pembelajaran kooperatif tipe Student Team Achievement Division (STAD) pada siwa kelas VIII G SMP Negeri 2 Sukoharjo semester genap tahun pelajaran 2015/2016. Penelitian ini adalah Penelitian Tindakan Kelas (PTK) yang dilaksanakan sebanyak 2 siklus, masing-masing siklus melalui 4 tahapan yaitu : (1) perencanaan, (2) pelaksanaan tindakan, (3) observasi dan (4) refleksi. Subjek penelitian adalah seluruh siswa kelas VIII G SMP Negeri 2 Sukoharjo semester genap tahun pelajaran 2015/2016 sebanyak 32 siswa. Teknik pengumpulan data dengan dokumentasi dan tes. Berdasarkan hasil penelitian ini dapat disimpulkan bahwa penggunaan model pembelajaran kooperatif tipe STAD dapat meningkatkan prestasi belajar Matematika materi lingkaran pada kelas VIII G di SMP Negeri 2 Sukoharjo semester genap tahun pelajaran 2015/2016. Hal tersebut ditunjukkan dengan nilai rata-rata prestasi belajar siswa siswa mengalami peningkatan yaitu sebelum tindakan sebesar 64,19, pada siklus I sebesar 73,6 dan pada siklus II sebesar 81,2. Selain itu, jumlah siswa yang mencapai dan melampaui nilai KKM $(\mathrm{KKM}=75)$ dari kondisi awal yang tuntas hanya 8 siswa(25\%) meningkat menjadi 15 siswa $(46,875 \%)$ pada siklus I, kemudian meningkat lagi menjadi 29 siswa $(90,625 \%)$ pada siklus II , dan sudah melebihi target minimal (80\%).
\end{abstract}

Kata kunci : Model pembelajaran Student Team Achievement Division (STAD), Prestasi Belajar Matematika.

\begin{abstract}
The aim of this research is to improve mathematics learning of VIII G students of achievement SMP Negeri 2 Sukoharjo semester II at academic year 2015/ 2016 by means of applying cooperative learning model type Student Teams-Achievement Division (STAD). This research is a classroom action research which was conducted in two cycles. The subject of this research is the VIII G students with total number of 32 students consisting of 14 male students and 18 female students. This research is conducted by the mathemathics science teacher of VIII G, other social science teacher as colleague who observes the learning process, and the Headmaster as subject to source of the data. The method of collecting data is conducted by test technique, observation and documentation. This classroom action research is conducted in two cycles, each of which consisting of four stages namely, planning, implementation, observation and reflection. The result of data analysis shows that by means of applying cooperative learning model type STAD there is an improvement of the mathemathics achievement of VIII G students of SMP Negeri 2 Sukoharjo Sukoharjo semester II at academic year 2015/2016. There is an improvement of
\end{abstract}


the achievement average: 71,2 5before the reserach, 75 after first cycle and 82after the second cycle. Besides, the classical completeness average is also improved: $25 \%$ before the reserach,46,875\% after first cycle, and 90,625\% after the second cycle.

Key word: STAD cooperative learning model type and mathemathics learning outcomes

\section{PENDAHULUAN}

Pembelajaran pada dasarnya merupakan upaya pendidik untuk membantu siswamelakukan kegiatan belajar.Tujuan pembelajaran adalah terwujudnya efisiensi dan efektivitas kegiatan belajar yang dilakukan peserta didik.Rendahnya hasil belajar siswa dapat dipengaruhi oleh faktor ekstern atau intern. Faktor ekstern yang mempengaruhi hasil belajar antara lain metode mengajar, kurikulum, hubungan antara guru dan siswa, serta sarana prasarana. Proses penilaian yang dilakukan selama ini semata-mata hanya menekankan pada penguasaan konsep (kognitif) yang dijaring dengan tes tulis obyektif dan subyektif sebagai alat ukurnya. Sehingga kondisi seperti ini menyebabkan guru kurang fokus pada pengembangan keterampilan proses anak dalam proses pembelajaran. Realitas ini mendorong siswa untuk menghapal pada setiap kali akan diadakan tes harian atau tes hasil belajar.

Menurut Gage dalam Sagala (2003), belajar adalah sebagai suatu proses dimana suatu organism berubah perilakunya sebagai akibat dari pengalaman.Menurut Nichol dalam Aunurrahman (2009), belajar merupakan kegiatan penting setiap orang, termasuk didalamnya belajar bagaimana seharusnya belajar.Hasil belajar ditandai dengan perubahan tingkah laku. Walaupun tidak semua perubahan tingkah laku merupakan hasil belajar, akan tetapi aktivitas belajar umumnya disertai perubahan tingkah laku.

Mengingat peneliti sekaligus guru mata pelajaran Matematika maka perlunya penguasaan standar kompetens menentukan unsur bagian lingkaran serta ukurannya semaksimal mungkin sehingga siswabenar-benar dapat menyerap materi tersebut semaksimal mungkin pula. Tampaknya perlu adanya perubahan paradigma dalam menelaah proses belajar siswadan interaksi antara guru dan siswadengan 
pengajaran yang inovatif. Sistem pengajaran yang memberi kesempatan kepada sesama siswauntuk bekerja sama dalam menyelesaikan tugas-tugas yang terstruktur disebut sebagai sistem "pembelajaran gotong royong" atau "cooperative learning", dalam hal ini guru bertindak sebagai fasilitator.Dari observasi awal pada kelas VIII G, diperoleh hasil belajar Dari 32 siswa 8 siswa (25\%) yang mencapai nilai Kriteria Ketuntasan Minimal (KKM), 24 siswa (75\%) dibawah nilai Kriteria Ketuntasan Minimal (KKM), sedangkan rata-rata kelas 71,25. Dapat disimpulkan bahwa prestasi belajar siswakelas VIII G masih rendah.

Dari kondisi di atas maka perlu penggunaan model pembelajaran yang dapat membangkitkan semangat siswa, menyenangkan dan menarik. Dalam hal ini ditawarkan model pembelajaran yang inovatif yaitu pembelajaran kooperatif (cooperative learning). Pembelajaran kooperatif dapat diartikan belajar bersamasama, saling membantu antara satu dengan yang lain dalam belajar dan memastikan bahwa setiap orang dalam kelompok mencapai tujuan yang telah ditentukan. Dengan demikian, dapat dipahami bahwa pembelajaran kooperatif menyangkut teknik pengelompokan yang di dalamnya siswabekerja terarah pada tujuan.Belajar bersama dalam kelompok kecil yang umumnya terdiri dari 5-6 orang.

Menurut Slavin (2005), pembelajaran kooperatif adalah suatu model pembelajaran dimana siswabelajar dan bekerja dalam kelompok-kelompok kecil secara kolaboratif yang anggotanya 4-6 orang dengan struktur kelompok heterogen. Selanjutnya Stahl (1994) menyatakan pembelajaran kooperatif dapat meningkatkan belajar siswalebih baik dan meningkatkan sikap tolong-menolong dalam perilaku sosial.

Pada pembelajaran kooperatif terdapat beberapa tipe, salah satu diantaranya adalah pembelajaran koperatif tipe Student Team Achievement Division (STAD). Tipe ini dikembangkan oleh Slavin dan merupakan salah satu tipe kooperatif yang menekankan pada adanya aktifitas dan interaksi di antara siswa untuk saling memotivasi dan saling membantu dalam menguasai materi pelajaran guna mencapai prestasi yang maksimal. Pada prosesnya, pembelajaran kooperatif tipe Student Team Achievement Division (STAD) melalui 5 tahapan yang meliputi : 
penyajian materi, kegiatan kelompok, tes individual, penghitungan skor perkembangan individu dan pemberian penghargaan kelompok.Langkah-langkah pembelajaran kooperatif tipe STAD ini didasarkan pada langkah-langkah kooperatif yang terdiri atas 6 langkah atau fase. Fase-fase dalam pembelajaran ini seperti disajikan dalam tabel berikut :

Tabel 1.Fase-fase Pembelajaran Kooperatif Tipe STAD Fase Kegiatan Guru

\section{Fase 1}

Menyampaikan tujuan dan memotivasi siswa

Menyampaikan semua tujuan pembelajaran yang ingin dicapai pada pembelajaran tersebut dan memotivasi siswa belajar.

\section{Fase 2}

Menyajikan/menyampaikan informasi

Menyajikan informasi kepada siswa dengan jalan mendemonstrasikan atau lewat bahan bacaan.

\section{Fase 3}

Mengorganisasikan siswa dalam kelompok-kelompok belajar
Menjelaskan kepada siswa bagaimana caranya membentuk kelompok belajar dan membantu setiap kelompok agar melakukan transisi secara efisien.

\section{Fase 4}

Membimbing kelompok bekerja dan belajar

Membimbing kelompok-kelompok belajar pada saat mereka mengerjakan tugas mereka.

\section{Fase 5}

Evaluasi

Mengevaluasi hasil belajar tentang materi yang telah diajarkan atau masing-masing kelompok mempresentasikan hasil kerjanya.

\begin{tabular}{ll}
\hline Fase 6 & Mencari cara-cara untuk menghargai baik \\
Memberikan penghargaan & upaya maupun hasil belajar individu dan \\
& kelompok.
\end{tabular}

Berdasarkan uraian di atas, dapat dirumuskan tujuan penelitian ini adalah: "Untuk meningkatkan prestasi belajar Matematika materi Lingkaran melalui 
penggunaan model pembelajaran kooperatif tipe Student Team Achievement Division (STAD) pada siwa kelas VIII G SMP Negeri 2 Sukoharjo semester genap tahun pelajaran 2015/2016."

\section{METODE PENELITIAN}

Penelitian ini adalah Penelitian Tindakan Kelas (PTK), merupakan suatu pencermatan terhadap kegiatan yang sengaja dimunculkan, dan terjadi dalam sebuah kelas (Arikunto, 2010). Penelitian ini dilaksanakan di SMPNegeri 2 Sukoharjo. Tahap-tahap pelaksanaan kegiatan dilakukan selama empat bulan mulai bulan Januari sampai dengan bulan April 2016. Subjek penelitian tindakan kelas ini adalah siswa kelas VIIIGSMP Negeri 2 Sukoharjosemester genaptahun pelajaran 2015/ 2016 sebanyak 32 siswa yang terdiri dari 14 siswa laki-laki dan 18 siswa perempuan, sebagai subjekpenerima tindakan, sedangkan untuk subjekpelaku tindakan adalah guru matematika kelas VIII G selaku guru, teman sejawat selaku subjekyang melakukan observasi proses pembelajaran, Kepala Sekolah selaku subjeksumber data.Metode pengumpulan data dilakukan melalui teknik tes, observasi dan dokumentasi.

Teknik pengumpulan data yang digunakan adalah: observasi, dokumentasi dan tes. Metode tes digunakan untuk memperoleh data tentang kondisi awal siswa adalah hasil tes sebelum penelitian, selama penelitian dan setelah penelitian dilaksanakan. Observasi yang digunakan adalah observasi sistematis, yaitu observasi yang dilakukan oleh pengamat dengan menggunakan pedoman sebagai instrumen pengamatan.

Instrumen yang digunakan dalam penelitian ini adalah: lembar observasi, tes, dan dokumentasi. Lembar observasi dugunakan peneliti sebagai pedoman melakukan observasi atau pengamatan guna memperoleh data yang akurat dalam pengamatan.Lembar observasi juga digunakan untuk memonitor dan mengevaluasi setiap tindakan agar kegiatan observasi tidak terlepas dari konteks permasalahan dan tujuan penelitian.Tes digunakan untuk melihat seberapa besar penguasaan 
konsep IPS siswa terhadap materi yang diajarkan.Hasil tes dianalisis guna mengetahui penguasaan materi lingkaran setelah dilakukan model pembelajaran STAD.

Indikator keberhasilan dalam penelitian ini adalah apabila nilai rata-rata tes siswa sekurang-kurangnya 75 dan banyak siswa dengan nilai di atas batas ketuntasan minimal (KKM) yaitu $\geq 75,0$ mencapai $\geq 80 \%$.

\section{HASIL DAN PEMBAHASAN}

Berdasarkan observasi kondisi awal, pada kelas VIII G, dimana belum diterapkan model pembelajaran kooperatif tipe STAD diperoleh prestasi belajar yang disajikan pada daftar di bawah ini.

Tabel 2. Prestasi Belajar Siswa pada Kondisi Awal

\begin{tabular}{llcl}
\hline No & Ketuntasan & Jumlah & $\%$ \\
\hline 1 & Tuntas & 8 & 25 \\
\hline 2 & Tidak Tuntas & 24 & 75 \\
\hline Jumlah & & 32 & 100 \\
\hline Nilai Tertinggi & 96 & \\
\hline Nilai Terendah & 61 & \\
\hline Nilai Rata rata & 71,25 & \\
\hline
\end{tabular}

Dari 32 siswa hanya 8 siswa (25\%) yang mencapai nilai Kriteria Ketuntasan Minimal $(\mathrm{KKM}=75)$, dan $24 \operatorname{siswa}(75 \%)$ dibawah nilai Kriteria Ketuntasan Minimal (KKM), sedangkan rata-rata kelas 71,25. Dapat disimpulkan bahwa prestasi belajar siswakelas VIII G masih rendah. Setelah melihat kondisi di atas maka peneliti selaku guru Matematika merasa perlu untuk mengubah model pembelajaran yang lama (konvensional) digantikan dengan model pembelajaran kooperatif tipe Student Team Achievement Division (STAD), dengan harapan 
prestasi belajar Matematika dengan materi Lingkaran di kelas VIII G mengalami peningkatan.

\section{Tindakan Siklus I}

Guru (peneliti) menyiapkan perangkat, antara lain : Daftar kelompok diskusi peserta didik, Lembar Kerja Peserta Didik, Naskah soal tes, Lembar penilaian, Silabus dan RPP. Tahap perencanaan tindakan siklus I dengan model pembelajaran kooperatif tipe Student Team Achievement Division (STAD) sebagai berikut Pelaksanaan Tindakan Siklus I sebanyak 2 kali pertemuan (1) Pertemuan pertama: (a) Guru mengucapkan salam, dilanjutkan presensi peserta didik, memberikan apersepsi materi prinsip dasar keliling lingkaran (b) Guru membagi menjadi 6 kelompok dari keseluruhan (32 peserta didik), masing-masing kelompok terdiri dari 5-6 anggota, dipastikan anggotanya heterogen (c) Guru membagikan lembar dikerjakan secara berkelompok.(d) Guru memonitor kegiatan peserta didik. (e)Guru meminta perwakilan kelompok presentasi.(f) Guru membagi soal tes I dikerjakan mandiri (g) Guru mengucapkan salam penutup.(2) Pertemuan kedua: (a) Guru mengucapkan salam, melakukan presensi peserta didik. dan memberikan tentang materiluas lingkaran.(b) Guru menyajikan materi luas lingkaran .(c) Guru meminta siswamenempatkan diri pada kelompoknya.(d) Guru membagikan lembar kerja tentangluas lingkaran tiap siswa dikerjakan berkelompok. (e) Guru memonitor kegiatan peserta didik.(f) Guru meminta wakil dari kelompok untuk melakukan presentasi.(g) Guru membagikan soal tes dikerjakan mandiri.(h) Guru mengucapkan salam penutup.Hasil nilai siklusI yang diikuti sebanyak 32 siswasebagai berikut

Tabel 3. Prestasi Belajar Siswa pada Siklus I

\begin{tabular}{llcc}
\hline No & Ketuntasan & Jumlah & $\%$ \\
\hline 1 & Tuntas & 15 & 46,875
\end{tabular}


2

Tidak Tuntas

Jumlah

32

100

\section{Nilai Tertinggi}

Nilai Terendah

Nilai Rata rata

\section{6}

64

75

Daftar hasil tes hasil tes siklus I, menunjukkan bahwa dari jumlah keseluruhan (32 siswa) kelas VIII G, 15 siswa (46,875 \%) mencapai nilai Kriteria Ketuntasan Minimal (KKM) dan rata-rata kelasnya 75. Hasil evaluasi siklus I terlihat hasil rataan dari tes menunjukkan peningkatan yang berarti jika dibandingkan nilai pada kondisi awal, saat belum diterapkan model pembelajaran kooperatif tipe Student Team Achievement Division (STAD), dari 32 siswakelas VIII G, 15 siswa( 46,875 \%) mencapai dan melampaui dari Kriteria Ketuntasan Minimal (KKM), mengalami peningkatan menjadi 46,875 \% jika dibanding dengan kondisi awal dimana hanya $8 \operatorname{siswa}(25 \%)$ yang mencapai dan melampaui KKM.

Dengan adanya peningkatan prestasi belajar siswa kelas VIII G, menunjukkan bahwa penerapan model pembelajaran kooperatif tipe STAD sangat efektif. Tidak hanya peningkatan pada sisi akademis saja, tetapi kesemangatan belajar siswa juga mengalami peningkatan.

Memperhatikan target pencapaian minimal presentase ketuntasan yaitu $80 \%$ dari jumlah siswakelas VIII G, sedangkan pada siklus I mencapai persentase ketuntasan $46,875 \%$, berarti masih perlu adanya beberapa pembenahan dalam perencanaan dan tindakan. Beberapa hal yang perlu lebih ditekankan dalam perencanaan dan tindakan, antara lain : (1) Motivasi, agar kesemangatan siswadalam proses pembelajaran lebih meningkat. (2) Guru memberikan pengertian bahwa perbedaan tingkat akademis dalam suatu kelompok memang merupakan salah satu ciri dari model STAD, dimaksudkan siswa yang lebih tinggi tingkat akademisnya membantu temannya yang mengalami kesulitan, sehingga terjadi 
interaksi yang menarik.(3) Diinformasikan pada siswabahwa nilai yang dicapai tiap siswapada siklus I dihitung peningkatannya dibanding kondisi awal, sehingga akan tampak nilai perkembangan setiap peserta didik.

\section{Tindakan Siklus II}

Guru menyiapkan terlebih dahulu perangkat pembelajaran, sebelum masuk pada kegiatan pembelajaran Matematika pada siklus II dengan menggunakan model pembelajaran kooperatif tipe STAD antara lain: Daftar kelompok diskusi yang terdiri 4 peserta didik, Lembar Kerja Peserta Didik, Naskah soal tes , Lembar penilaian, Silabus dan RPPPelaksanaan Tindakan Siklus II sebanyak 2 kali pertemuan :(1) Pertemuan pertama: (a) Guru mengucapkan salam, dilanjutkan melakukan presensi siswa. (b) Guru memotivasi kepada siswatentang materi cara menentukan panjang busur lingkaran. (c) Guru menyajikan materi menentukan panjang tali busur lingkaran .(d) Guru membagi menjadi 8 kelompok, masingmasing kelompok terdiri dari 4 anggota, tiap kelompok dipastikan anggotanya heterogen. (e) siswa menempatkan diri pada kelompoknya.(f) Guru membagikan lembar kerja tentang cara menentukan busur ,tali busur, kepada tiap siswadikerjakan secara berkelompok.(g) Guru memonitor kegiatan peserta didik.(h) Guru meminta anggota salah satu kelompok melakukan presentasi,(i) Guru memberikan soal tes dikerjakan mandiri (j) Guru mengucapkan salam penutup (2) Pertemuan kedua: (a) Guru mengucapkan salam, dilanjutkan melakukan presensi peserta didik.(b) Guru memotivasi dan memberikan apersepsi kepada siswatentang materi luas juring dan tembereng .(c) Guru menyajikan materi luas juring dan tembereng (d) Guru meminta siswamenempatkan diri pada kelompoknya.(e) Guru membagikan lembar kerja tentang materi luas juring lingkaran pada siswa dikerjakan secara kelompok (f) Guru memonitor jalannya diskusi, dan berjalan lancar. (g) Guru meminta salah satu wakil kelompok melakukan presentasi. (h) Guru membagikan soal tes kepada tiap siswauntuk dikerjakan mandiri.(i)Guru mengucapkan salam penutup.

Hasil nilai siklus Ilyang diikuti sebanyak 32 siswa adalah sebagai berikut : 
Tabel 4. Prestasi Belajar Siswa pada Siklus I

\begin{tabular}{llcc}
\hline No & Ketuntasan & Jumlah & $\%$ \\
\hline 1 & Tuntas & 29 & 90,625 \\
\hline 2 & Tidak Tuntas & 3 & 9,375 \\
\hline Jumlah & & 32 & 100 \\
\hline Nilai Tertinggi & 98 & \\
\hline Nilai Terendah & 70 & \\
\hline Nilai Rata rata & 82 & \\
\hline
\end{tabular}

Berdasarkan tabel4 di atas hasil tes siklus II, menunjukkan bahwa dari jumlah keseluruhan (32 siswa) kelas VIII G, 29 siswa(90,625\%) mencapai nilai Kriteria Ketuntasan Minimal (KKM) dan rata-rata kelasnya 82

Memperhatikan hasil rataan dari tes I dan II dengan menggunakan model pembelajaran kooperatif tipe Student Team Achievement Division (STAD) pada siklus II ini, menunjukkan peningkatan jika dibandingkan dengan hasil pada siklus I, demikian juga untuk siswalebih bersemangat dalam mengikuti proses pembelajaran.

Pada siklus I siswa yang mencapai dan melampaui nilai KKM ada 15 siswa(46,875\%), sedangkan pada siklus II ada 29 siswa $(90,625 \%)$ berarti mengalami peningkatan 14 siswa $(43,75 \%)$. Demikian juga untuk nilai rata-rata kelasnya meningkat dari 75 (siklus I) menjadi 82 (siklus II).

Tahapan-tahapan pada siklus I yang telah dikoreksi pada siklus II merupakan suatu proses pembelajaran yang nampaknya akan tetap dikembangkan dan dilaksanakan pada pembelajaran dengan kompetensi dasar yang berikutnya.Kebaikan yang telah dicapai perlu ditingkatkan, sedangkan kelemahankelemahan yang terjadi perlu dihilangkan dan akan disesuaikan dengan tema kompetensi dasarnya. Berikut ini rekapitulasi perbandingan antara kondisi awal ,siklus I dan siklus II pada kelas VIII G SMP Negeri 2 Sukoharjo : 
Tabel 5. Rekapitulasi Prestasi Belajar Siswa

\begin{tabular}{llllllll}
\hline & & \multicolumn{2}{l}{ Kondisi Awal } & \multicolumn{2}{l}{ Siklus 1 } & \multicolumn{2}{l}{ Silkus II } \\
\hline No & Ketuntasan & jumlah & $\%$ & jumlah & $\%$ & jumlah & $\%$ \\
\hline 1 & Tuntas & 8 & 25 & 15 & 46,875 & 29 & 90,625 \\
\hline 2 & Tidak Tuntas & 24 & 75 & 17 & 53,125 & 3 & 9,375 \\
\hline Jumlah & 32 & 100 & 32 & 100 & 32 & 100 \\
\hline Nilai Tertinggi & 96 & & 96 & & 98 & \\
\hline Nilai Terendah & 61 & & 64 & & 70 & \\
\hline Nilai Rata Rata & 71,25 & & 75 & & 82 & \\
\hline
\end{tabular}

Dengan memperhatikan hasil tes siswapada daftar dan diagram diatas, mulai dari kondisi awal yang masih menggunakan model ceramah dan demonstrasi ( 25 $\%$ ) mencapai dan melampaui KKM) kemudian berganti model yaitu dengan model pembelajaran kooperatif tipe Student Team Achievement Division (STAD) pada siklus I (46,875\% mencapai dan melampaui KKM) dan siklus II $(90,625 \%$ mencapai dan melampaui KKM), terlihat jelas peningkatan hasil belajar setelah menggunakan model pembelajaran kooperatif tipe Student Team Achievement Division (STAD). Dapat disimpulkan bahwa penggunaan model pembelajaran kooperatif tipe Student Team Achievement Division (STAD) telah berhasil meningkatkan prestasi belajar Matematika dengan materi lingkaran bagi siswa kelas VIII G SMP Negeri 2 Sukoharjo.

\section{SIMPULAN}

Berdasarkan hasil Penelitian Tindakan Kelas yang dilakukan pada pembelajaran matematika dengan penerapan model STAD pada siswa kelas VIII G SMP N Negeri 2 Sukoharjo Tahun Pelajaran 2015/2016. Penggunaan model pembelajaran kooperatif tipe STAD dapat meningkatkan hasil belajar matematika siswa kelas VIII G SMP Negeri 2 Sukoharjo tahun pelajaran 2015/ 2016. Hasil penelitian ini menunjukkan adanya peningkatan pada hasil belajar matematika 
siswa. Hal ini dapat dilihat dari nilai rata-rata hasil belajar matematika siswa juga mengalami peningkatan yaitu sebelum tindakan sebesar 71,25 pada siklus I sebesar 75 dan pada siklus II sebesar 82. Selain itu, presentase ketuntasan belajar siswa, yaitu sebelum tindakan sebesar $25 \%$, pada siklus I sebesar $46,87 \%$ dan pada siklus II sebesar 90,625\%.

\section{DAFTAR PUSTAKA}

Abdurrahman, M, 2003. Pendidikan Bagi Anak Berkesulitan Belajar. Jakarta: Rineka Cipta.

Arikunto, S. 2006. Prosedur Penelitian Suatu Pendekatan Praktik (Edisi Revisi VI). Jakarta: Rineka Cipta.

Aunurrahman. 2009. Belajar dan Pembelajaran.Bandung: Alfabeta.

Sagala, S. 2003. Konsep dan Makna Pembelajaran. Bandung: Alfabeta.

Stahl, R.J. 1994. Cooperative Learning in Social Studies : A Handbookfor Teacher. USA : Addison Wesley Publishing Company, Inc

Slavin, R. 2005.Cooperative Learning. Bandung: Nusa Media.

Sudjana, N. 2005. Dasar-dasar Proses Belajar Mengajar. Jakarta: Sinar Baru Algensido.

Trianto. 2009. Mendesain Model Pembelajaran Inovatif-Progresif: Konsep Landasan dan Implementasinya pada Kurikulum Tingkat Satuan Pendidikan (KTSP).

UU.2003. UU Nomor 20 Tahun 2003 Pasal 1 Ayat (1).http//www.bing.com.diakses Pada Tanggal 5 Maret 2015 pukul 15.00 